\title{
A highly sensitive, selective and turn-off fluorescent sensor based on phenylamine-oligothiophene derivative for rapid detection of $\mathrm{Hg}^{2+}$
}

Xingxing Wu, Qingfen Niu,* Tianduo Li, Yuezhi Cui, Shanshan Zhang

Shandong Provincial Key Laboratory of Fine Chemicals, Qilu University of Technology, Jinan 250353, People's Republic of China

\begin{abstract}
A fluorescent sensor based on phenylamine-oligothiophene derivative 3TEA was reported. This sensor showed highly selective and sensitive detection of $\mathrm{Hg}^{2+}$ ion in $\mathrm{THF} / \mathrm{H}_{2} \mathrm{O}(7 / 3, \mathrm{v} / \mathrm{v})$ solution through fluorescence quenching. The detection was unaffected by other competitive metal ions. The detection limit was found to be as low as $3.952 \times 10^{-7} \mathrm{M}$ estimated by the titration method. The recognition process is reversible and confirmed by EDTA experiment. The turn-off fluorescence behavior of mercury interaction with 3TEA has been found to be so fast that it can be used for its qualitative as well as quantitative estimation.
\end{abstract}

Keywords: Fluorescence sensor; Mercury ion; Oligothiophene; Quenching. 
* To whom the correspondence should be addressed

E-mail: qf_niu1216@qlu.edu.cn

Telephone: $+86(531) 89631760$

Fax number: +86(531)89631208 


\section{Introduction}

In recent years, mercury has received much attention due to its high toxicity. The widespread pollution of mercury resulted from a variety of natural and anthro-pogenic sources [1-2] like oceanic and volcanic emissions [3-4], solid waste incineration as well as gold mining [5]. Exposure to mercury, even at very low concentrations, induces digestive, brain, kidney and endocrine system diseases [6], and it especially causes neurological diseases [7]. Mercury poisoning can lead to several diseases such as acrodynia, Alzheimer disease and Mina Mata disease [8]. Owing to the continual concern over mercury in the environment and its deleterious effects on human health [9-10], the search for practical analytical methods for mercury assays has received considerable attention [11-16] in the recent years. Many of the available approaches have been devoted to screening for $\mathrm{Hg}^{2+}$ by use of spectrophotometry [17], atomic absorption spectroscopy [18], gas chromatography and liquid chromatography [19]. Unfortunately, these methods typically have some disadvantages such as expensive instruments and sophisticated, multi-step sample pre-treatments [20]. Therefore, it is highly desirable to develop simple and advanced techniques with high selectivity and sensitivity for rapid detection of $\mathrm{Hg}^{2+}$ ion in the environment and biological systems.

The recognition and sensing of biologically and environmentally important metal ions by fluorescence technique has emerged as a significant goal in the 
area of chemical sensors in the recent years [21-22]. Among the various assays that are available for the detection of cations, the techniques based on fluorescence sensors present a large number of appealing advantages in terms of high sensitivity and selectivity, generally non-destructive character, desirable photo-physical properties, good water solubility, low cost, facile operation, response time, local observation as well as the wide spread availability of equipment for analysis [23-25]. Currently, a great number of efforts have been made to develop fluorescent sensors for the detection of mercury and mercuric salts with sensitivity and selectivity [26-34].

Our previous studies reported the synthesis, photophysical and morphology properties of a phenylamine-oligothiophene-based derivative 3TEA [35] (Fig. 1). In the current study, in order to expand our interest to the fluorescent chemosensor for metal-ion screening studies, we continue to explore its cation-sensing properties. However, the investigated results demonstrated that 3TEA exhibited high selectivity, sensitivity and rapid fluorescence response to $\mathrm{Hg}^{2+}$ ion over other metal ions including $\mathrm{Na}^{+}, \mathrm{K}^{+}, \mathrm{Ag}^{+}, \mathrm{Ca}^{2+}, \mathrm{Al}^{3+}, \mathrm{Co}^{2+}, \mathrm{Cu}^{2+}$, $\mathrm{Ni}^{2+}, \mathrm{Zn}^{2+}, \mathrm{Pb}^{2+}, \mathrm{Cd}^{2+}, \mathrm{Fe}^{3+}, \mathrm{Fe}^{2+}$ and $\mathrm{Cr}^{3+}$ in $\mathrm{THF} / \mathrm{H}_{2} \mathrm{O}(7 / 3, \mathrm{v} / \mathrm{v})$ solution. 


\section{Experimental}

\subsection{Reagents}

Unless otherwise stated, solvents and reagents were of analytical grade from commercial suppliers, and were used without further purification. Metal salts were purchased from Sigma-Aldrich and used as received. THF was spectrometric grade and purchased from Qingdao Yage Chemical Reagent Company. Water was deionized with a Milli-QSP reagent water system (Millipore) to a specific resistivity of $18.4 \mathrm{M} \Omega \mathrm{cm}$. THF and deionized water were used in all of the experiments. All other reagents are analytical grade and also from Beijing Chemical works. The salts used in stock solutions of metal ions were $\mathrm{NaNO}_{3}, \mathrm{Ca}\left(\mathrm{NO}_{3}\right)_{2} \cdot 4 \mathrm{H}_{2} \mathrm{O}, \mathrm{Al}\left(\mathrm{NO}_{3}\right)_{3} \cdot 9 \mathrm{H}_{2} \mathrm{O}, \mathrm{Pb}\left(\mathrm{NO}_{3}\right)_{2}, \mathrm{Cu}\left(\mathrm{NO}_{3}\right)_{2} \cdot 3 \mathrm{H}_{2} \mathrm{O}$, $\mathrm{AgNO}_{3}, \mathrm{Zn}\left(\mathrm{NO}_{3}\right)_{2} \cdot 6 \mathrm{H}_{2} \mathrm{O}, \mathrm{Cd}\left(\mathrm{NO}_{3}\right)_{2} \cdot 4 \mathrm{H}_{2} \mathrm{O}, \mathrm{Fe}\left(\mathrm{NO}_{3}\right)_{3} \cdot 9 \mathrm{H}_{2} \mathrm{O}, \mathrm{Co}\left(\mathrm{NO}_{3}\right)_{2} \cdot 6 \mathrm{H}_{2} \mathrm{O}$, $\mathrm{Ni}\left(\mathrm{NO}_{3}\right)_{2} \cdot 6 \mathrm{H}_{2} \mathrm{O}, \mathrm{KNO}_{3}, \mathrm{Hg}\left(\mathrm{NO}_{3}\right)_{2} \cdot \mathrm{H}_{2} \mathrm{O}, \mathrm{FeCl}_{2} \cdot 4 \mathrm{H}_{2} \mathrm{O}$ and $\mathrm{CrCl}_{3} \cdot 6 \mathrm{H}_{2} \mathrm{O}$. 3TEA was prepared as reported previously [35].

\subsection{Apparatus}

All UV-visible absorption spectra were recorded with a Shimadzu UV-2600 spectrophotometer at room temperature. All fluorescence measurements were carried out on Hitachi F-4600 fluorescence spectrophotometer with a scan rate at $1200 \mathrm{~nm} / \mathrm{min}$. The excitation wavelength was set at $330 \mathrm{~nm}$. The slits for excitation and emission were set at $5 \mathrm{~nm} / 5 \mathrm{~nm}$, respectively.

\subsection{General procedures for spectral determination}


All tests described in this paper were carried out at room temperature. All the metal salts of $\mathrm{Na}^{+}, \mathrm{K}^{+}, \mathrm{Ag}^{+}, \mathrm{Ca}^{2+}, \mathrm{Fe}^{3+}, \mathrm{Al}^{3+}, \mathrm{Co}^{2+}, \mathrm{Ni}^{2+}, \mathrm{Cu}^{2+}, \mathrm{Zn}^{2+}, \mathrm{Pb}^{2+}$, $\mathrm{Cd}^{2+}, \mathrm{Hg}^{2+}, \mathrm{Fe}^{2+}$ and $\mathrm{Cr}^{3+}$ were dissolved in water to prepare the stock solution with the concentration of $1.0 \times 10^{-3} \mathrm{M}$. 3TEA was dissolved in THF to give the stock solution $\left(1.0 \times 10^{-3} \mathrm{M}\right)$ and diluted with a mixed solution of $\mathrm{THF} / \mathrm{H}_{2} \mathrm{O}$ to prepare the analytical solution $\left(1.0 \times 10^{-5} \mathrm{M}\right)\left(\mathrm{THF} / \mathrm{H}_{2} \mathrm{O}, 7 / 3\right.$, v/v). The stock solution of the metal cations and 3TEA was used directly in the spectroscopic measurement. For the sensitivity measurement, different concentrations of $\mathrm{Hg}^{2+}$ ions were added to the assay solution, and the fluorescence spectra were recorded. The selectivity was checked by addition of $\mathrm{Na}^{+}, \mathrm{K}^{+}, \mathrm{Ag}^{+}, \mathrm{Ca}^{2+}, \mathrm{Fe}^{3+}$, $\mathrm{Al}^{3+}, \mathrm{Co}^{2+}, \mathrm{Ni}^{2+}, \mathrm{Cd}^{2+}, \mathrm{Zn}^{2+}, \mathrm{Pb}^{2+}, \mathrm{Cu}^{2+}, \mathrm{Fe}^{2+}$ and $\mathrm{Cr}^{3+}$ in to the stock solution.

\subsection{Association constant calculation}

Generally, for the formation of 1:1 complexation species formed by the receptor and the guest cation, the following Benesi-Hildebrand [36] equation was used to determining the association constants $\left(\mathrm{K}_{\mathrm{a}}\right)$.

$$
\frac{1}{F-F_{0}}=\frac{1}{\left\{K_{a} \times\left(F_{\max }-F_{0}\right) \times\left[H g^{2+}\right]\right\}}+\frac{1}{F_{\max }-F_{0}}
$$

where $\mathrm{F}$ is the fluorescence intensity at $497 \mathrm{~nm}$ at any given $\mathrm{Hg}^{2+}$ concentration, $\mathrm{F}_{0}$ is the fluorescence intensity at $497 \mathrm{~nm}$ in the absence of $\mathrm{Hg}^{2+}$, and Fmax is the maxima fluorescence intensity at $497 \mathrm{~nm}$ in the presence of $\mathrm{Hg}^{2+}$ in $\mathrm{THF} / \mathrm{H}_{2} \mathrm{O}\left(7 / 3\right.$, v/v) solution. The association constant $\mathrm{K}_{\mathrm{a}}$ was evaluated 
graphically by plotting $1 /\left(\mathrm{F}-\mathrm{F}_{0}\right)$ against $1 /\left[\mathrm{Hg}^{2+}\right]$. Data were linearly fitted according to Eq. (1) and the $K_{a}$ value was obtained from the slope and intercept of the line.

\subsection{The detection limit calculation}

The detection limit (DL) of $\mathrm{Hg}^{2+}$ ion using sensor 3TEA was determined from the following equation: $\mathrm{DL}=\mathrm{K} \times \mathrm{SD} / \mathrm{S}$, where $\mathrm{K}=3$; $\mathrm{SD}$ is the standard deviation of the blank solution; $\mathrm{S}$ is the slope of the calibration curve [37-38].

\subsection{Fluorescence quantum yield measurement}

Fluorescence quantum yield was determined using optically matching solutions of quinine sulfate $\left(\Phi=0.55\right.$ in $\left.0.5 \mathrm{~mol} / \mathrm{L} \mathrm{H}_{2} \mathrm{SO}_{4}\right)$ as standard at an excitation wavelength of $330 \mathrm{~nm}$. Excitation and emission slit widths were modified to adjust the luminescent intensity in a suitable range. All the spectroscopic measurements were performed at least in triplicate and averaged.

$$
\Phi_{F u}=\frac{\left(\Phi_{F s}\right)(F A u)(A s)\left(\eta_{u}^{2}\right)}{(F A s)(A u)\left(\eta_{s}^{2}\right)}
$$

In the equation (1), $\mathrm{s}$ is the standard, $\mathrm{u}$ is the unknown, $F A$ is the integrated area under the corrected emission spectrum, $A$ is the absorbance at the excitation wavelength, $\eta$ is the the refractive index of the solution, and $\Phi_{F}$ is the fluorescence quantum yield.

\section{Results and discussion}




\subsection{Cation-sensing ability of $3 T E A$}

To explore the sensing ability of 3TEA, 15 metal cations including $\mathrm{Na}^{+}, \mathrm{K}^{+}$, $\mathrm{Ca}^{2+}, \mathrm{Co}^{2+}, \mathrm{Ni}^{2+}, \mathrm{Cu}^{2+}, \mathrm{Zn}^{2+}, \mathrm{Fe}^{3+}, \mathrm{Pb}^{2+}, \mathrm{Ag}^{+}, \mathrm{Cd}^{2+}, \mathrm{Hg}^{2+}, \mathrm{Al}^{3+}, \mathrm{Cr}^{3+}$ and $\mathrm{Fe}^{2+}$ was investigated in $\mathrm{THF} / \mathrm{H}_{2} \mathrm{O}(7 / 3$, v/v) by fluorescence and UV-vis measurements. On excitation at $330 \mathrm{~nm}$, sensor 3TEA $\left(10 \mu \mathrm{M}, \mathrm{THF} / \mathrm{H}_{2} \mathrm{O}(7 / 3, \mathrm{v} / \mathrm{v})\right)$ gave emission band with $\lambda_{\max } 497 \mathrm{~nm},\left(\Phi_{\mathrm{F}}=0.61\right)$. To our surprise, the fluorescence intensity of 3TEA $(10 \mu \mathrm{M})$ in $\mathrm{THF} / \mathrm{H}_{2} \mathrm{O}(7 / 3, \mathrm{v} / \mathrm{v})$ strongly quenched in the presence of the $\mathrm{Hg}^{2+}$ ion (2.0 equiv) $\left(\Phi_{\mathrm{F}}=0.08\right)($ Fig. 2a), accompanied by a green-blue color fluorescence turn-off response (Fig. 2a, inset), while other metal cations did not affect the fluorescence intensity significantly. The interaction between 3TEA and $\mathrm{Hg}^{2+}$ provides fluorescence quenching pathway. The fluorescence quenching of the chemosensor 3TEA may occur by the excitation energy transfer from the ligand to the metal d-orbital and/or lignad to metal charge transfer $(\mathrm{LMCT})$. The observed quenching efficiency $\left(\left(1-\mathrm{F} / \mathrm{F}_{0}\right) \times\right.$ $100 \%$ ) at $497 \mathrm{~nm}$ was $85 \%$ by $\mathrm{Hg}^{2+}$, where the other metal ions caused small quenching in fluorescence (Fig. 2b). These obvious observations indicate that 3TEA displays clear 'turn-off' fluorescence response and considerably high selectivity towards $\mathrm{Hg}^{2+}$ ion in aqueous THF solution.

Fig. 2a

Fig. 2b 
The fluorescence titrations of 3TEA $(10.0 \mu \mathrm{M})$ was performed in the presence of various concentrations of $\mathrm{Hg}^{2+}$ ion in $\mathrm{THF} / \mathrm{H}_{2} \mathrm{O}(7: 3$, v/v) in Fig. 3 . Upon addition of an increasing amount of $\mathrm{Hg}^{2+}$ ion leads to a continuous fluorescence quenching around $497 \mathrm{~nm}$, and the fluorescence intensity remains constant after approximately 1.0 equiv of $\mathrm{Hg}^{2+}$ being added. A good linear relationship between the fluorescence intensity at $497 \mathrm{~nm}$ and the $\mathrm{Hg}^{2+}$ concentration was found in the range of $0-10 \mu \mathrm{M}$ (Fig. 3, inset). These observations above indicate that 3TEA and $\mathrm{Hg}^{2+}$ have a 1:1 binding ratio. Furthermore, in the Job's plot (Fig. S1), a maximum fluorescence change was observed with a 0.5 molar fraction of ionophore to $\mathrm{Hg}^{2+}$ for 3TEA, which further revealed the formation of a 1:1 complex. In addition, the binding constant $\left(\mathrm{K}_{\mathrm{a}}\right)$ of 3 TEA with $\mathrm{Hg}^{2+}$ was determined to be $5.048 \times 10^{6} \mathrm{M}^{-1}$ with a good linear relationship $(\mathrm{R}=0.99737$, Fig. S2), as obtained by fitting the data to the Benesi-Hildebrand expression. By using above-mentioned fluorescence titration results, the DL for $\mathrm{Hg}^{2+}$ ion was calculated to be $3.952 \times 10^{-7} \mathrm{M}$ (Fig. S3). The DL was sufficiently low to detect submillimolar concentration of the $\mathrm{Hg}^{2+}$ ion, which belongs the range found in many chemical and biological systems.

Fig. 3

Fig. 4

In this study, the sensor 3TEA likely chelates metal ion via the amine $\mathrm{N}$ 
atom of the aniline moiety, as other reported [39-41]. Mercury nitrate has structure in which covalent bonding is important and easily form amine-mercury(II) salt $\pi$-complexes with amine ligand, specially primary amine 3TEA, increasing the co-ordination number of the metal to three. The proposed binding model between 3TEA and $\mathrm{Hg}^{2+}$ was suggested in Scheme S1. To determine the nature of the complexation between 3TEA and $\mathrm{Hg}^{2+}$, FT-IR spectra of 3TEA was recorded in the presence of $\mathrm{Hg}^{2+}$ ion (Fig. S4). IR spectra of $3 \mathrm{TEA}^{35}$ and $3 \mathrm{TEA}-\mathrm{Hg}^{2+}$ complex exhibited that the peak at 3381 and 3474 $\mathrm{cm}^{-1}$ corresponding to the characteristic $\mathrm{NH}_{2}$ group stretching vibration absorption of 3TEA was shifted to a higher wavenumber $\left(3525\right.$ and $3580 \mathrm{~cm}^{-1}$ ) upon addition of $\mathrm{Hg}^{2+}$ (1.0 equiv). At the same time, the peak at $1380 \mathrm{~cm}^{-1}$ that could be attributed to the nitro $(\mathrm{N}=\mathrm{O})$ group stretching vibration. Furthermore, the peak at $2176 \mathrm{~cm}^{-1}$ that could be attributed to the $\mathrm{C} \equiv \mathrm{C}$ group stretching vibration. A substantial red shift upon coordination of the N-donor atom of the amine group indicates electron transfer from oligothiophene to phenylamine after coordination to the mercury center in the case of 3TEA. Our experimental results presented are in good agreement with the reported literature. Therefore, these obvious changes can be explained by the amine group of 3TEA participated in the formation of amine-mercury(II) salt $\pi$-complex, confirming a 1:1 stoichiometry for the $3 \mathrm{TEA}-\mathrm{Hg}^{2+}$ complex.

To further explore the possibility of using 3TEA as a practical ion-selective fluorescent chemosensor for $\mathrm{Hg}^{2+}$, competition experiments were carried out. As 
can be seen from Fig. 5, 3TEA exhibited a significant selectivity towards $\mathrm{Hg}^{2+}$ ion. The deviation of the fluorescence quenching in the presence of other metal cations was less than $3 \%$. This indicated that $\mathrm{Hg}^{2+}$ ion detection by 3TEA was unaffected by the presence of other competitive metal ions. According to the results, it could be assumed that 3TEA had potential prospects as a selective detector of $\mathrm{Hg}^{2+}$ ion in aqueous environment. Moreover, the EDTA experiments were conducted to examine the reversibility of 3TEA toward $\mathrm{Hg}^{2+}$ ion in aqueous solution $\left(\mathrm{THF} / \mathrm{H}_{2} \mathrm{O}, 7 / 3, \mathrm{v} / \mathrm{v}\right)$ as shown in Fig. 6, the solution changed from colorless to green-blue when EDTA (5.0 equiv) was added to the solution of $3 \mathrm{TEA} / \mathrm{Hg}^{2+}$, and the fluorescence was turned on in several seconds. These results indicate that the coordination process is reversible and thus 3TEA is a reversible chemosensor for $\mathrm{Hg}^{2+}$ in aqueous solutions. Thus, the development of reversible fluorescent chemosensors for the determination of $\mathrm{Hg}^{2+}$ with "off-on" light and high selectivity is highly desirable [42].

\section{Fig. 5.}

Fig. 6.

\subsection{Reaction time on sensing $\mathrm{Hg}^{2+}$ ion}

Reaction time is an important factor for sensors, thus the effect of the reaction time on the binding process of $\mathrm{Hg}^{2+}$ ion to 3TEA was investigated (Fig. 7(a)). Following the addition of $\mathrm{Hg}^{2+}$ ion $(20 \mu \mathrm{M})$ to 3TEA $(10 \mu \mathrm{M})$, the 
fluorescence intensity of 3TEA was quenched rapidly, reaching a stable value within 2 min and then remaining constant after 2 min. Moreover, in order to make sure the $2 \mathrm{~min}$ is enough for the trace-amount measurement, the time-effect with $\mathrm{Hg}^{2+}$ ion of lower concentrations such as $10 \mu \mathrm{M}$ was investigated (Fig. 7(b)). The result further demonstrated that the fluorescence intensity of 3TEA was quenched quickly and also reached a stable value within $2 \mathrm{~min}$. The rapid, stable complexation of $\mathrm{Hg}^{2+}$ ion by 3TEA and the resulting quick response profile are important features for robust, real time detection of $\mathrm{Hg}^{2+}$ ion by portable device in field. In contrast, many previously reported fluorescent sensors showed responses to $\mathrm{Hg}^{2+}$ ion in the time range of tens of minutes, generally attributed to slower sensor reaction processes [43-44].

Fig. 7(a)

Fig. 7(b)

\section{Conclusions}

In summary, a phenylamine-oligothiophene-based fluorescent sensor 3TEA was reported and its sensing ability for a wide range of metal cations was investigated. 3TEA displayed highly selective, sensitive and rapid response to $\mathrm{Hg}^{2+}$ ion through fluorescence quenching in $\mathrm{THF} / \mathrm{H}_{2} \mathrm{O}(7 / 3, \mathrm{v} / \mathrm{v})$ solution. The detection limit was found to be as low as $3.952 \times 10^{-7} \mathrm{M}$. The coordination process of sensor 3TEA and $\mathrm{Hg}^{2+}$ was chemically reversible with EDTA. In 
addition, the sensor 3TEA can detect $\mathrm{Hg}^{2+}$ ion on-line and in real time, permitting its incorporation into a portable mercury detection kit in aqueous THF environment.

\section{Acknowledgment}

We gratefully acknowledge the support by NSF China No. 21176147/21376125/21276149 and Program for Scientific Research Innovation Team in Colleges and Universities of Shandong Province.

\section{References}

[1] E.M. Nolan, S.J. Lippard, Chem. Rev. 108 (2008) 3443.

[2] A.P. de Silva, H.Q.N. Gunaratne, T. Gunnlaugsson, A.J.M. Huxley, C.P. McCoy, J.T. Rademacher, T.E. Rice, Chem. Rev. 97 (1997) 1515.

[3] J.M. Benoit, W.F. Fitzgerald, A.W. Damman, Environ. Res. 78 (1998) 118.

[4] A. Benzoni, F. Zino, E. Franchi, Environ. Res. 77 (1998) 68.

[5] O. Malm, Environ. Res. 77 (1998) 73.

[6] F. Wang, S.W. Nam, Z. Guo, S. Park, J. Yoon, Sens. Actuators B 161 (2012) 948.

[7] V. Bhalla, M. Roopa, M. Kumar, P.R. Sharma, T. Kaur, Inorg. Chem. 51 (2012) 2150 . 
[8] S. Bose-O'Reilly, K.M. McCarty, N. Steckling, B. Lettmeier, Curr. Probl. Pediatr. Adolesc. Health Care 40 (2010) 186.

[9] Q. Wang, D. Kim, D.D. Dionysiou, G.A. Sorial, D. Timberlake, Environ. Pollut. 131 (2004) 323.

[10] M. Nendza, T. Herbst, C. Kussatz, A. Gies, Chemosphere 35 (1997) 1875.

[11] L. Lindenburg, M. Merkx, Chem. Bio. Chem. 13 (2012) 349.

[12] N.L. Rosi, C.A. Mirkin, Chem. Rev. 105 (2005) 1547.

[13] A. Burns, H. Ow, U. Wiesner, Chem. Soc.Rev. 35 (2006) 1028.

[14] O.S. Wofbeis, J. Mater. Chem. 15 (2005) 2657.

[15] H.N. Kim, M.H. Lee, H.J. Kim, J.S. Kim, J. Yoon, Chem. Soc. Rev. 37 (2008) 1465.

[16] M.I.J. Stich, L.H. Fischer, O.S. Wolfbeis, Chem. Soc. Rev. 39 (2010) 3102.

[17] M.S. Hosseini, H.H. Moghaddam, Talanta 67 (2005) 555.

[18] A.F. Danet, M.C. Bratu, M.C. Radulescu, A. Bratu, Sens. Actuators B 137 (2009) 12.

[19] H. Hashemi-Moghaddam, M. Saber-Tehrani, J. AOAC Int. 91 (2008) 1453.

[20] L.P. Wang, B.Z. Zheng, Y. Zhao, J. Du, D. Xiao, Anal. Methods 4 (2012) 2369. 
[21] M. Formica, V. Fusi, L. Giorgi, M. Micheloni, Coord. Chem. Rev. 256 (2012) 170.

[22] H.N. Kim, M.H. Lee, H.J. Kim, J.S. Kim, J. Yoon, Chem. Soc. Rev. 37 (2008) 1465.

[23] A.T. Wright, E.V. Anslyn, Chem. Soc. Rev. 35 (2006) 14.

[24] J. Liu, Y. Lu, J. Fluoresc. 14 (2004) 343.

[25] J.H. Lee, Z. Wang, J. Liu,Y. Lu, J. Am. Chem. Soc. 130 (2008) 14217.

[26] D. Udhayakumari, S. Velmathi, J. Lumin. 136 (2013) 117.

[27] E.S. Childress, C.A. Roberts, D.Y. Sherwood, C.L.M. LeGuyader, E.J. Harbron, Anal. Chem. 84 (2012) 1235.

[28] N.Y. Kwon, D. Kim, J.H. Son, G.S. Jang, J.H. Lee, T.S. Lee, Macromol. Rapid Comm. 32 (2011) 1061.

[29] L.Q. Guo, N. Yin, D.D. Nie, J.R. Gan, M.J. Li, F.F. Fu, G.N. Chen, Analyst $136(2011) 1632$.

[30] L.B. Zhang, L. Tao, B.L. Li, L. Jing, E.K. Wang, Chem. Commun. 46 (2010) 1476.

[31] Y.-K. Yang, S.-K. Ko, I. Shin, J. Tae, Org. Biomol. Chem. 7 (2009) 4590.

[32] W. Liu, L. Xu, H. Zhang, J. You, X. Zhang, R. Sheng, H. Li, S. Wu, P. Wang, Org. Biomol. Chem.7 (2009) 660. 
[33] E.M. Nolan, S.J. Lippard, Chem. Rev. 108 (2008) 3443.

[34] S.-K. Ko, Y.-K. Yang, J. Tae, I. Shin, J. Am. Chem. Soc. 128 (2006) 14150.

[35] Q.F. Niu, Y.Q. Lu, H.J. Sun, X.Y. Li, X.T. Tao, Dyes Pigments 97 (2013) 184.

[36] V.S. Jisha, A.J. Thomas, D. Ramaiah, J. Org. Chem. 74 (2009) 6667.

[37] M. Shortreed, R. Kopelman, M. Kuhn, B. Hoyland, Anal. Chem. 68 (1996) 1414.

[38] W. Lin, L. Yuan, Z. Cao, Y. Feng, L. Long, Eur. J. Chem. 15 (2009) 5096.

[39] J. Barluenga, A.M. Bayon, J. Perez-Prieto, G. Asensio, Tetrahedron 40 (1984) 5053.

[40] K. Bahgat, A.S. Orabi, Polyhedron 21 (2002) 987.

[41] B. Gustafsson, M. Håkansson, A.T. Hutton, J.R. Moss, S. Jagner, Inorg. Chim. Acta 358 (2005) 1327.

[42] W. Lin, X. Cao, Y. Ding, L. Yuan, Q. Yu, Org. Biomol. Chem. 8 (2010) 3618.

[43] S. Ando, K. Koide, J. Am. Chem. Soc. 133 (2011) 2556.

[44] Y. Miyake, H. Togashi, M. Tashiro, H. Yamaguchi, S. Oda, M. Kudo, Y. Tanaka, Y. Kondo, R. Sawa, T. Fujimoto, T. Machinami, A. Ono, J. Am. Chem. Soc. 128 (2006) 2172. 


\section{Figure captions:}

Fig. 1. The structure of sensor 3TEA.

Fig. 2(a). Fluorescence spectra of 3TEA $\left(1.0 \times 10^{-5} \mathrm{M}\right)$ in aqueous solution $\left(\mathrm{THF} / \mathrm{H}_{2} \mathrm{O}, 7 / 3, \mathrm{v} / \mathrm{v}\right)$ in the presence of various cations (2.0 equiv). Inset: Photos of 3TEA without and with addition of $\mathrm{Hg}^{2+}$ under the irradiation of UV light at $365 \mathrm{~nm}$; (b) Fluorescence quenching degree of 3TEA $(10 \mu \mathrm{M})$ in the presence of $\mathrm{Hg}^{2+}(20 \mu \mathrm{M})$ and other metal ions (each $\left.20 \mu \mathrm{M}\right) . \mathrm{F}_{0}$ and $\mathrm{F}$ represented the fluorescence intensities of the 3TEA-based sensor system at $497 \mathrm{~nm}$ in the absence and presence of $\mathrm{M}^{\mathrm{n}+}$, respectively.

Fig. 3. Fluorescence emission spectra of 3TEA $\left(1.0 \times 10^{-5} \mathrm{M}\right)$ was titrated with $\mathrm{Hg}^{2+}\left(0-2.0\right.$ equiv) in aqueous solution $\left(\mathrm{THF} / \mathrm{H}_{2} \mathrm{O}, 7 / 3, \mathrm{v} / \mathrm{v}\right)$. Inset: Plot of the fluorescence intensity at $497 \mathrm{~nm}$ as a function of $\mathrm{Hg}^{2+}$ concentration.

Fig. 4. calibration curve of $3 \mathrm{TEA}-\mathrm{Hg}^{2+}$ in $\mathrm{THF} / \mathrm{H}_{2} \mathrm{O}(7 / 3, \mathrm{v} / \mathrm{v})$ solution.

Fig. 5. Metal specificity: the concentration of 3 TEA was $10 \mu \mathrm{M}$, the concentration of $\mathrm{Hg}^{2+}$ was $20 \mu \mathrm{M}$ and the other metal ions were used at $20 \mu \mathrm{M}$. Mix: the mixture of $\mathrm{Ni}^{2+}, \mathrm{Na}^{+}, \mathrm{Ca}^{2+}, \mathrm{Fe}^{3+}, \mathrm{K}^{+}, \mathrm{Zn}^{2+}, \mathrm{Cd}^{2+}, \mathrm{Pb}^{2+}, \mathrm{Ag}^{+}, \mathrm{Al}^{3+}, \mathrm{Co}^{2+}$, $\mathrm{Cu}^{2+}, \mathrm{Fe}^{2+}$ and $\mathrm{Cr}^{3+}$.

Fig. 6. Fluorescence spectra of 3TEA in the absence and presence of $\mathrm{Hg}^{2+}$ and EDTA. $\left[\mathrm{Hg}^{2+}\right]=20 \mu \mathrm{M},[3 \mathrm{TEA}]=10 \mu \mathrm{M},[\mathrm{EDTA}]=100 \mu \mathrm{M}$.

Fig. 7. Fluorescence quenching profile of addition $\mathrm{Hg}^{2+}(20 \mu \mathrm{M})$ (a) and $(10 \mu \mathrm{M})$ 
(b) to 3TEA $(10 \mu \mathrm{M})$ in $\mathrm{THF} / \mathrm{H}_{2} \mathrm{O}(7 / 3, \mathrm{v} / \mathrm{v})$ solution from 1 to $10 \mathrm{~min}$, respectively. 
Fig. 1

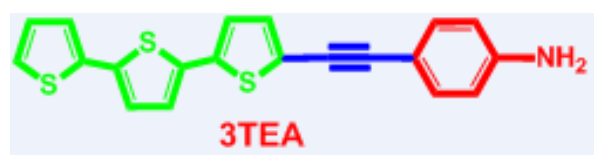

Fig. 2 (a)

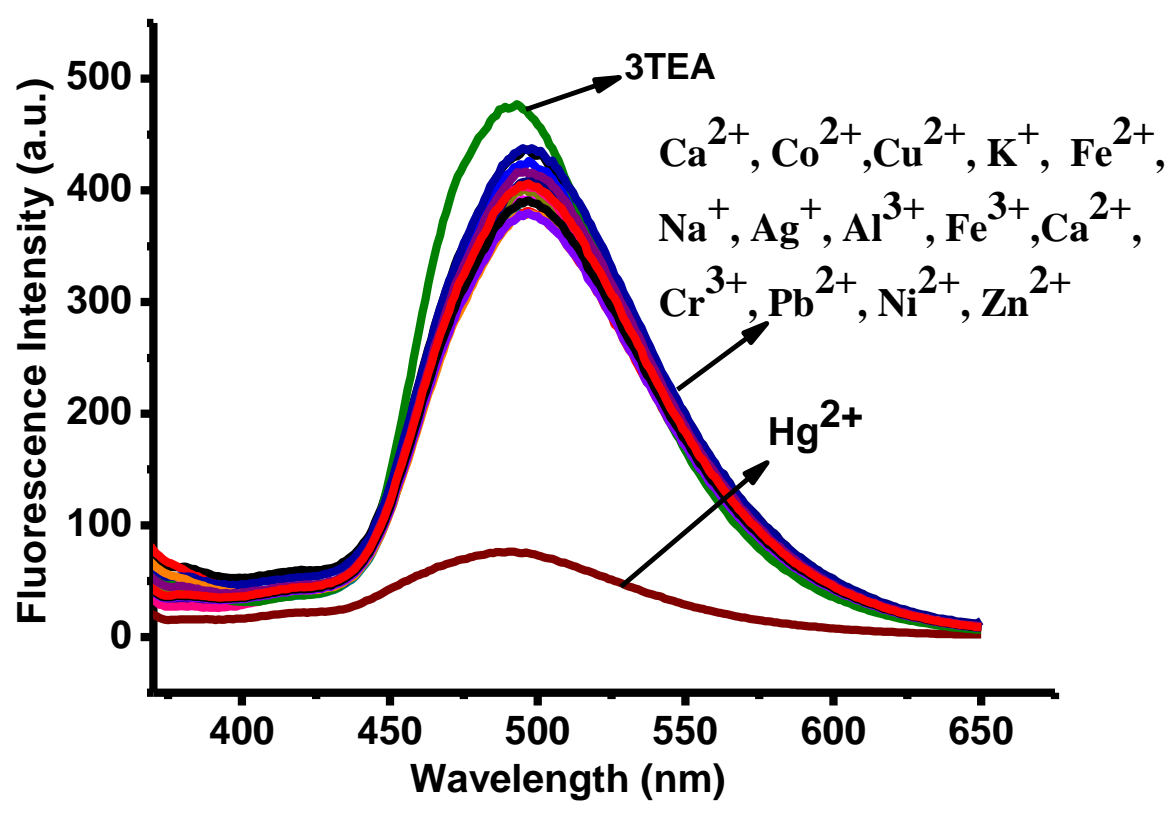

Fig. 2 (b) 


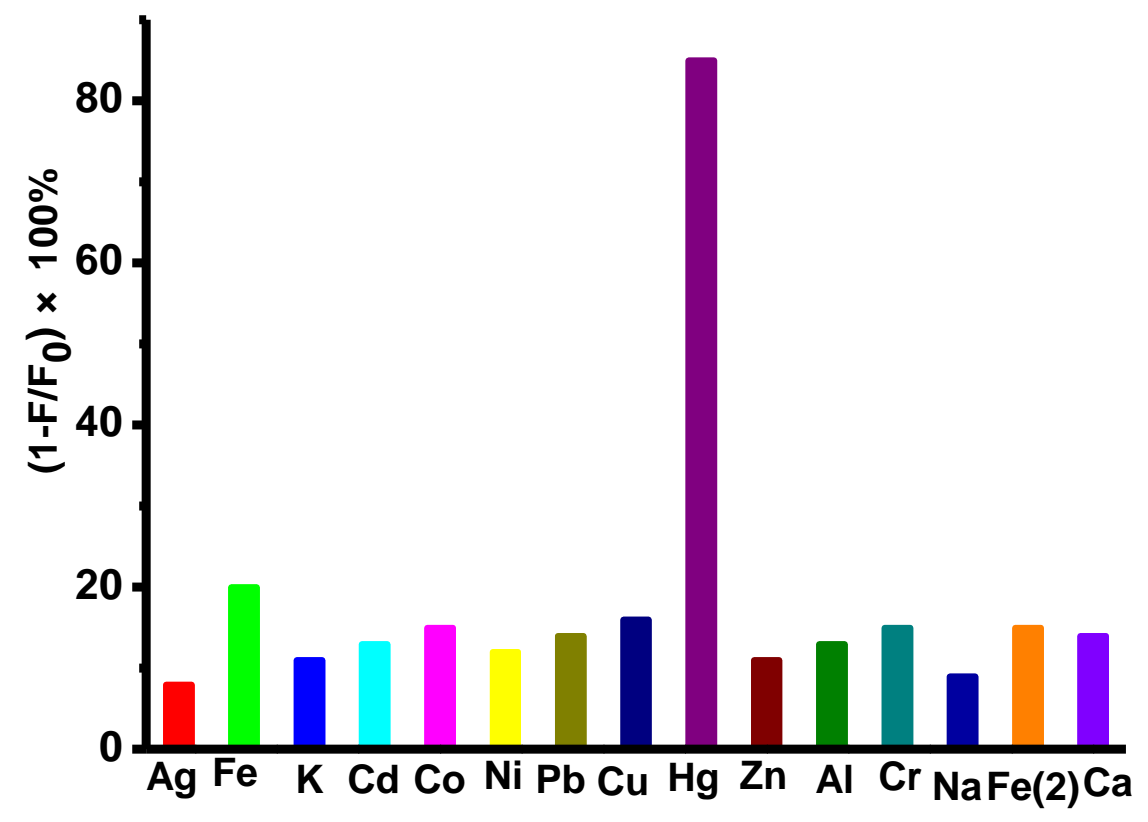

Fig. 3.

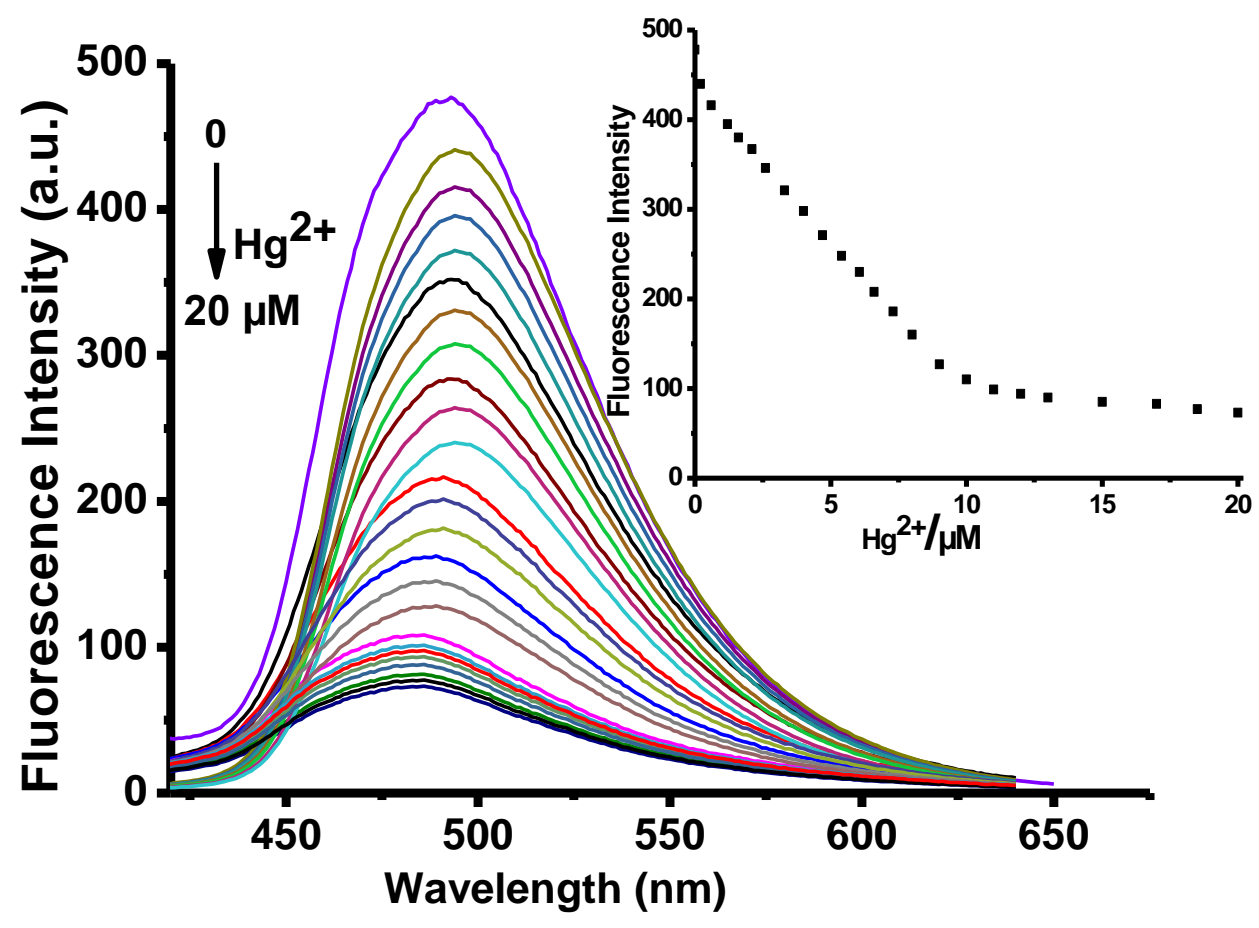


Fig. 4.

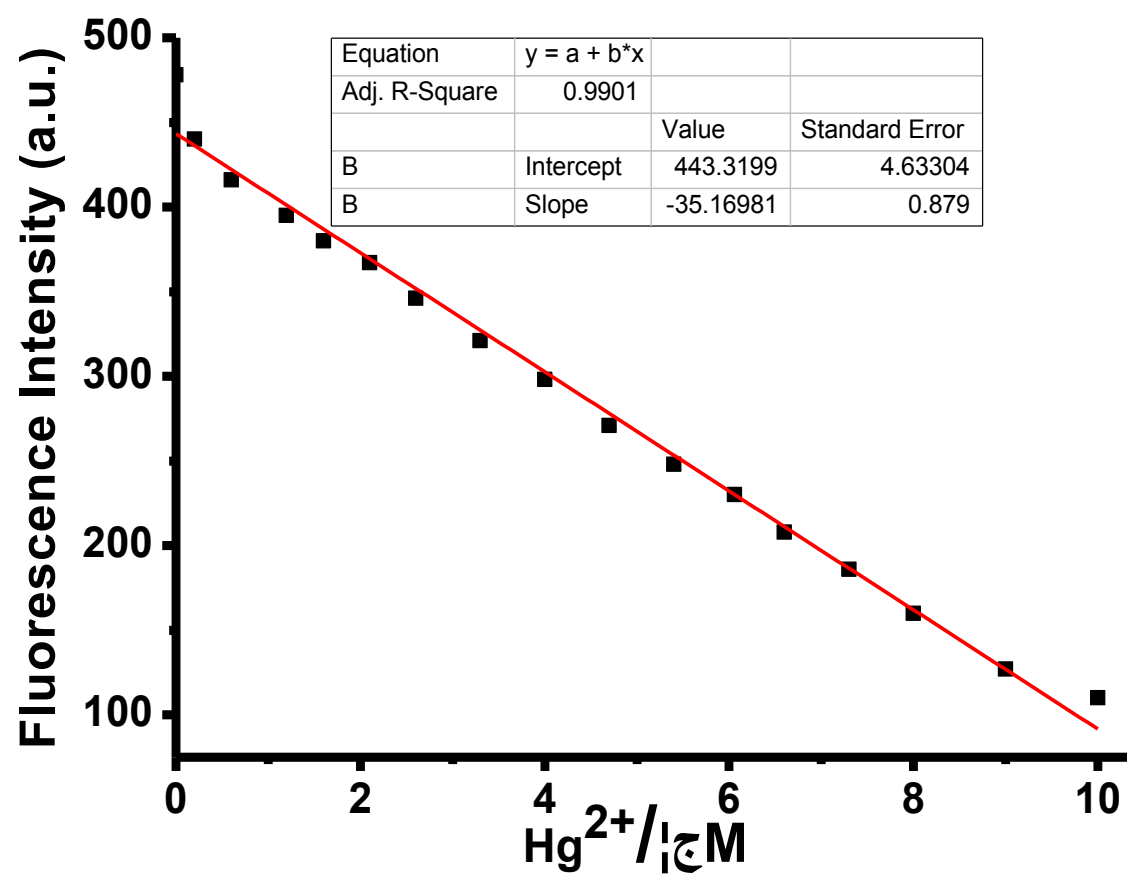

Fig. 5. 


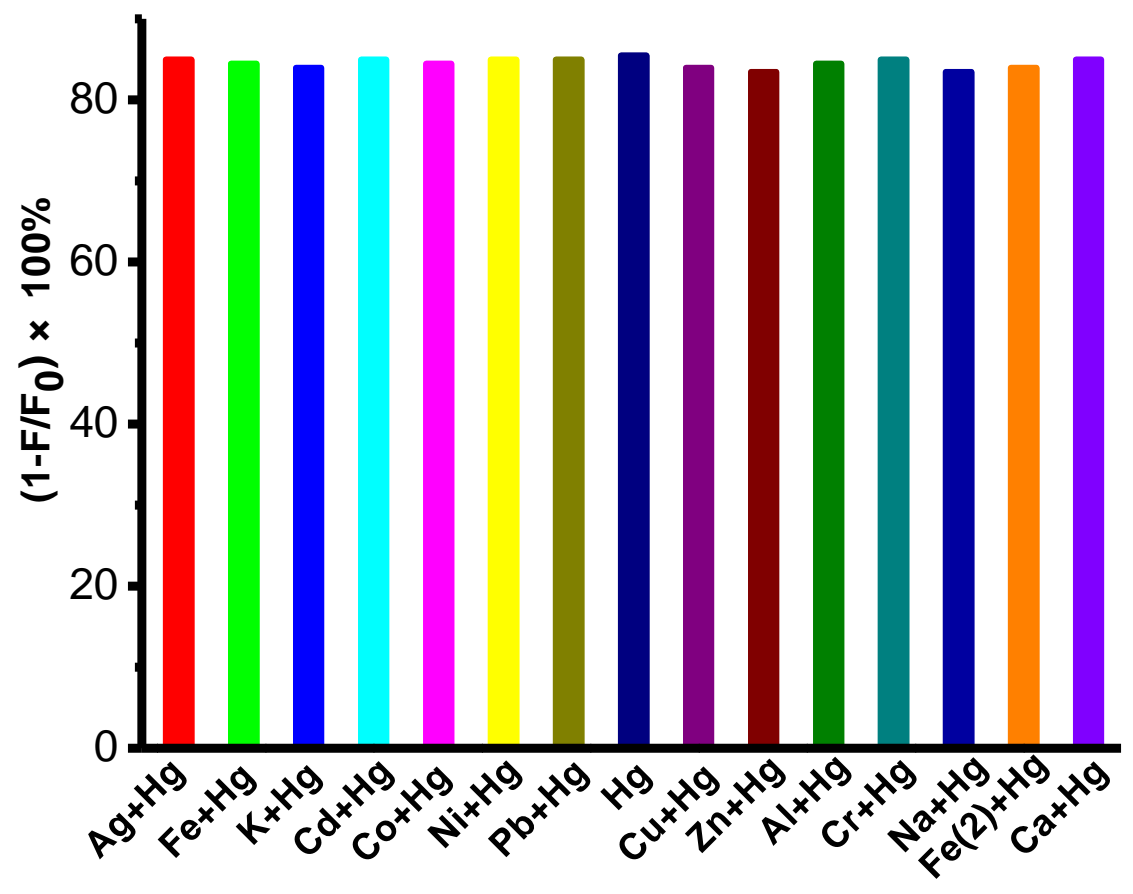

Fig. 6.

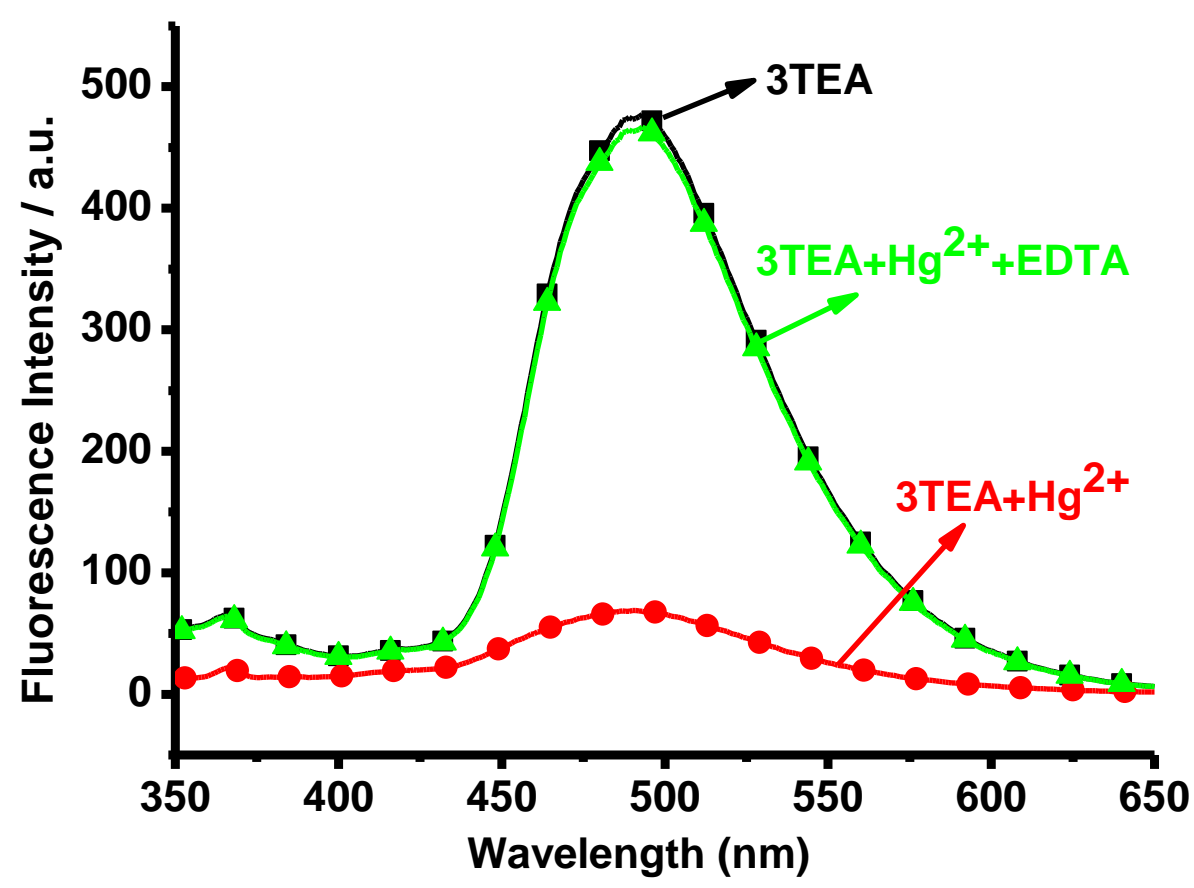


Fig. 7(a).

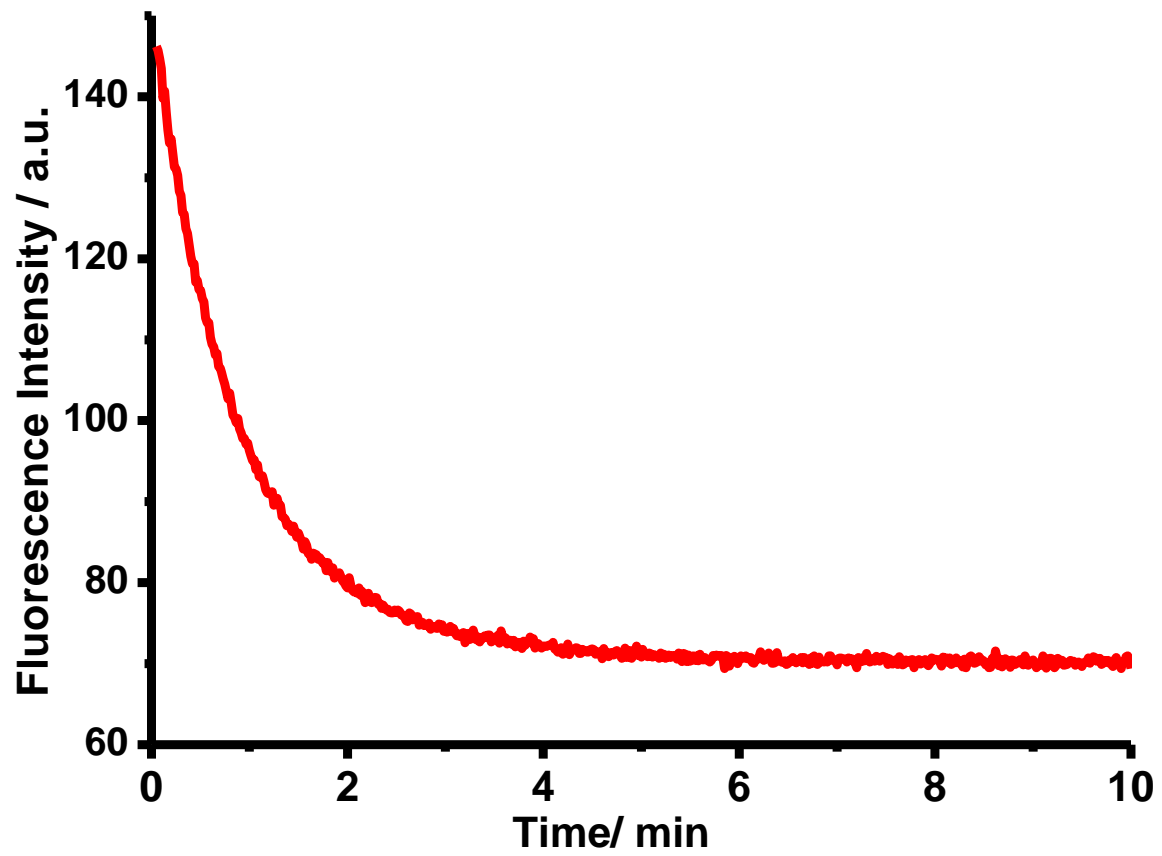

Fig. 7(b).

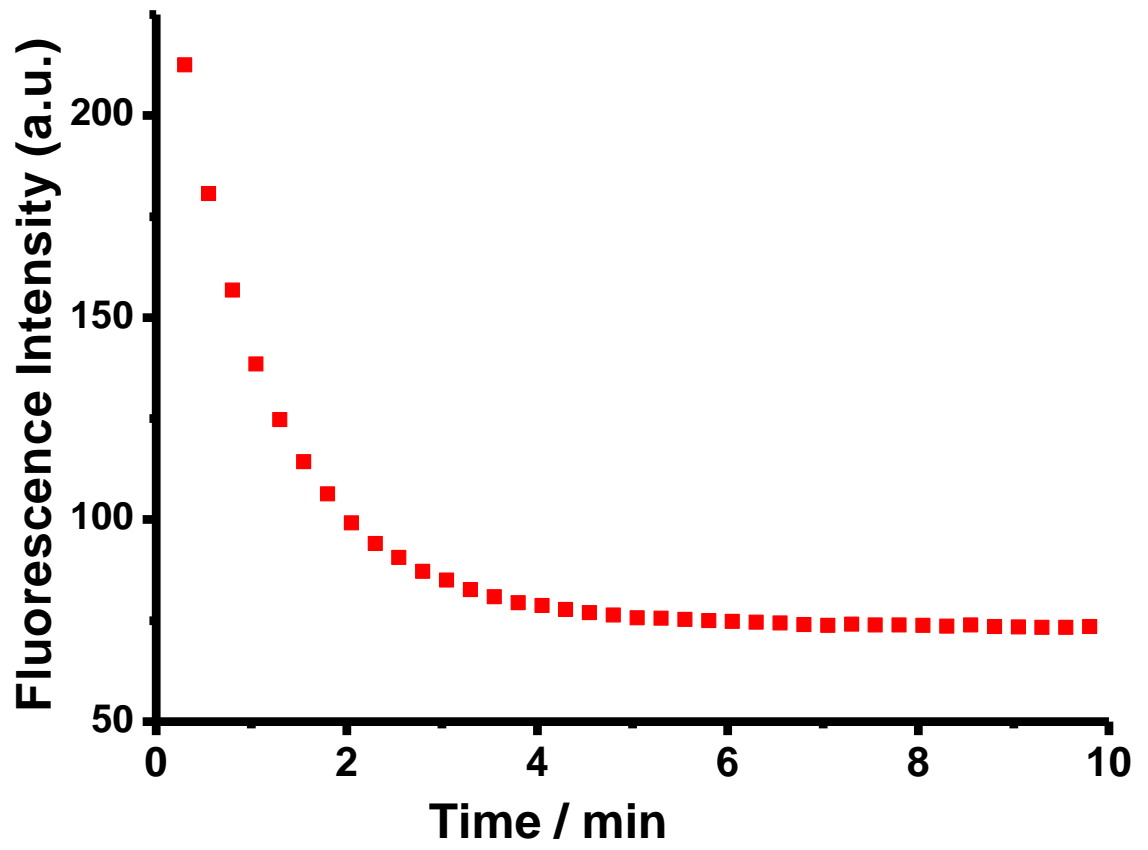

